GLÁUKS

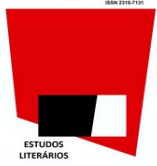

\title{
Entrevista com Felipe Lindoso
}

Joelma Santana Siqueira (Universidade Federal de Viçosa) Vivaldo Andrade dos Santos (Georgetown University)

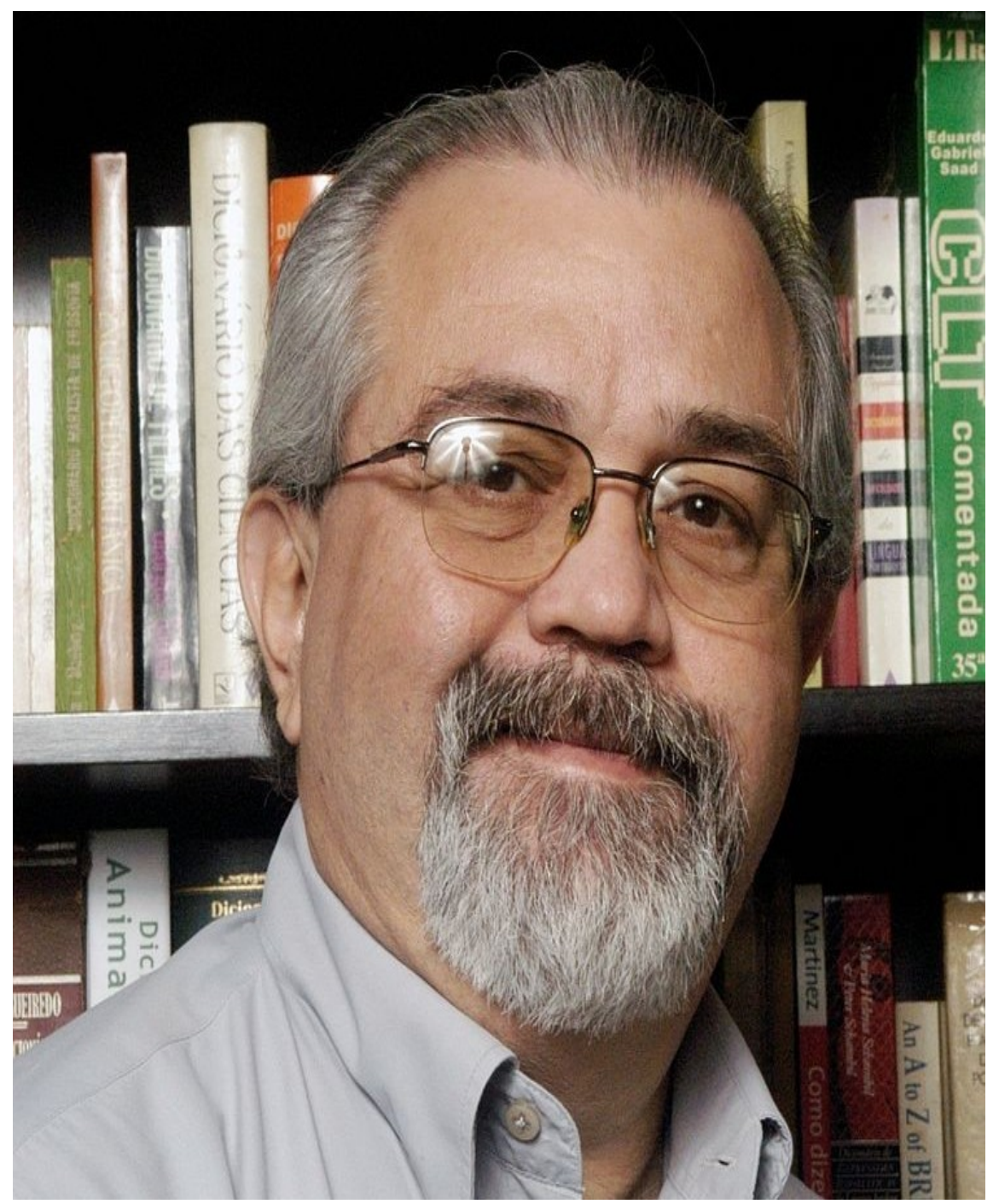

Gláuks: Revista de Letras e Artes - jul/dez 2020 - v. 20, n. 2 
Felipe Lindoso é jornalista, tradutor, editor e consultor de políticas públicas para o livro e a leitura. Foi sócio da Editora Marco Zero, diretor da Câmara Brasileira do Livro e consultor do Centro Regional para o Livro na América Latina e Caribe - CERLALC, órgão da UNESCO. É autor do livro O Brasil pode ser um país de leitores? Política para a cultura, política para o livro (2004) e responsável pelo blog "O Xis do Problema - políticas públicas para o livro e o mercado editorial" <www.oxisdoproblema.com.br> e por uma coluna do portal "PublishNews", voltado para notícias e informações sobre a indústria do livro $<$ www.publishnews.com.br>.

1. Prezado Felipe Lindoso, muito obrigada por nos conceder essa entrevista. Vamos começar pedindo que comente sobre como foi seu percurso de trabalho com o livro até chegar ao blog "O Xis do Problema - políticas públicas para o livro e o mercado editorial".

Começou com a pergunta que nos fizemos (eu, a Maria José Silveira e o Márcio Souza) quando éramos sócios da Marco Zero: Por que os livros ótimos que publicamos não vendem o suficiente? Como fazer que as massas comam o biscoito fino que produzimos". Para tentar responder isso, cheguei até aqui.

2. No texto "As dificuldades de internacionalização da literatura brasileira", publicado no "Xis do Problema", entre outros aspectos, você discutiu a posição da literatura brasileira na República Mundial das Letras e a ausência de políticas públicas consistentes de apoio à tradução e difusão dos escritores brasileiros. Algo a acrescentar ou reforçar, tendo em vista que o texto foi publicado em 2017 e que, de lá pra cá, as coisas só pioraram?

Por sorte o programa de apoio à tradução da $\mathrm{BN}$ não foi liquidado, embora contem com verbas mínimas. Mas há uma evidente desconexão do pouco que é feito (programa de bolsas), com quaisquer outras atividades governamentais ou não governamentais de promoção

Gláuks: Revista de Letras e Artes - jul/dez 2020 - v. 20, n. 2 
dos autores brasileiros no exterior. A revista "Machado de Assis Magazine", que publicava excertos de traduções de autores brasileiros foi descontinuada. O Itaú Cultural deixou de financiar e nenhuma outra instituição se interessou, apesar de ser um investimento relativamente baixo para a importância da iniciativa. A representação do Brasil na UNESCO votou pelo encerramento de um projeto de quase 90 anos, o Indez Translationarum, que compilava informação sobre a publicação de traduções junto às bibliotecas nacionais de todos os países membros da UNESCO. E por aí vai.

3. Você poderia nos falar um pouco sobre a curadoria do projeto "Conexões Itaú Cultural - Mapeamento Internacional da Literatura Brasileira"?

O projeto nasceu de uma pergunta do professor João Cezar de Castro Rocha feita ao Claudiney Ferreira, do Itaú Cultural: “Onde estão essas pessoas que estudam literatura brasileira no exterior?" Eu me integrei no projeto desde o começo, mas não estou mais vinculado a ele.

\section{Como os editores contribuem para a internacionalização da literatura brasileira?}

Como disse no artigo, a internacionalização da literatura brasileira é uma preocupação marginal para os editores, que eventualmente só ganham prestígio se um de seus editados for traduzido e publicado no exterior. Eventualmente usam seu prestígio e conexões para promover alguns de seus autores preferidos. Os estudiosos de literatura brasileira no exterior, alguns tradutores e agentes literários são os que fazem o que podem.

Gláuks: Revista de Letras e Artes - jul/dez, 2020 - v. 20, n. 2 
5. No Brasil, quem está interessado na literatura brasileira e, mais especificamente, em sua internacionalização?

Só os autores e os agentes literários, que fazem o que pode nesse cenário. O Ministério da Cultura foi extinto, a direção da BN está nas mãos de uma pessoa irrelevante, o Itamaraty dirigido por lunáticos terraplanistas que fecham com tudo que os EUA dizem e é capaz de logo pedirem para sair da UNESCO. O deserto do cócito, o rio de gelo eterno do último círculo do Inferno de Dante é o cenário que vivemos hoje no que diz respeito a políticas de livro e leitura no Brasil (e infelizmente não apenas em relação a isso).

Gláuks: Revista de Letras e Artes - jul/dez 2020 - v. 20, n. 2 